\title{
SURVIVAL OF ALKANE-DEGRADING MICROORGANISMS IN BIOGAS DIGESTATE COMPOST IN MICROCOSM EXPERIMENTS
}

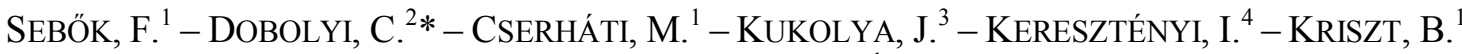 \\ - SZOBOSZLAY, S. ${ }^{1}$ \\ ${ }^{1}$ Department of Environmental Protection and Environmental Safety, Szent István University, \\ 2100 Gödöllö, Páter K. u. 1., Hungary \\ (phone: +36-28-522-000, fax: +36-28-410-804) \\ ${ }^{2}$ Regional University Centre of Excellence in Environmental Industry Based on Natural \\ Resources, Szent István University, \\ 2100 Gödöllö, Páter K. u. 1., Hungary \\ (phone: +36-28-522-000, fax: +36-28-410-804) \\ ${ }^{3}$ Department of Applied and Environmental Microbiology, Research Institute of Agro- \\ Environmental Sciences, National Agricultural Research and Innovation Centre, \\ H-1022 Budapest, Herman Ottó u. 15. \\ (phone: +36-1-7960-400) \\ ${ }^{4}$ MOL Hungarian Oil and Gas Plc., Downstream Development, Department of Environment \\ and Corrosion Protection, \\ H-2443 Százhalombatta, POB 1. \\ (phone: +36-20-914-5051, fax: +36-23-551-305) \\ *Corresponding author \\ e-mail:dobolyi.csaba@mkk.szie.hu \\ (Received 20 $0^{\text {th }}$ Jan 2013; accepted $22^{\text {nd }}$ June 2014)
}

\begin{abstract}
The objective of the study was to investigate composted biogas digestate as a suitable carrier for the microorganisms to be used in bioremediation of petroleum hydrocarbon contaminated soils. The survival kinetics of alkane-degrading microorganisms was examined in microcosm experiments by two means: measuring the number of colony forming units and their ability to produce $\mathrm{CO}_{2}$ from alkanes. The viability of the cells of Rhodococcus strains in the compost lasted longer than those of the tested Brevundimonas, Chryseobacterium, Pseudomonas strains. The decimal reduction time (D-value) used to express the survival of the microorganisms depended on their cell structure and biological features. Their survival was also affected by some abiotic factors: higher temperature $\left(26^{\circ} \mathrm{C}\right)$ decreased the survival of the microbes while the addition of burned perlite to the compost medium increased it. All of the tested microorganisms were able to use diesel oil as a sole carbon source both in the pure, unamended compost and in the compost-perlite mixture. Moreover, the addition of perlite increased the alkane-degrading activity for the tested Rhodococcus and fungal strains. These results indicate that biogas digestate composts can be suitable carriers for microorganisms used in bioremediation.
\end{abstract}

Keywords: bacteria, fungi, viability, hydrocarbon, bioremediation

\section{Introduction}

During the composting processes (mainly in their thermophilic phase), the majority of the starting organic materials become degraded due to microbial activity, pathogens and parasites perish as a consequence of the high temperature. Humus materials developing in the course of oxidative reconstruction can be utilized only minimally by

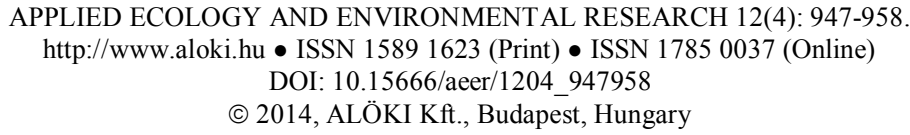


microorganisms, and their chemical structure becomes stable during the maturation phase (de Bertoldi et al., 1983; Haug, 1993). The composts control the inner microbial populations due to a permanent antimicrobial effect. The level and the ratio of the different microbial populations in the chemically stable compost are determined by the different reduction of their survival abilities. The amount of microorganisms belonging to different species and taxa is stabilized at various levels. Autochthonous microorganism species are permanently present in compost media. However, the majority of the microorganisms found in the environment, and even those that play a role in the initial phase of composting belonging to allochthonous species, cannot be detected in matured compost (Insam and de Bertoldi, 2007). The composts originated from traditional starting materials (communal solid wastes, agricultural/horticultural wastes) do not contain pathogens or parasites. Moreover, they resist secondary colonization by these organisms. On the other hand, they are not suitable for making the carrier material of microbes for storage and inoculation. Meanwhile, the demand for soil-compatible organic carrier materials has been growing in numerous soilbioremediation areas.

Biogas digestate, a by-product of anaerobic fermentation, is extremely rich in nitrogen and is microbiologically stable (Elfering et al., 1998; Maurer and Mueller, 2012). Its direct agricultural use as fertilizer is widespread, especially in the European Union where the amount of biomass degraded anaerobically exceeds 1500 million tons per year (Weiland, 2010). Recently, digestate can be composted in order to remove compounds that are chemically harmful or hygienically unacceptable for human and the environment (Bustamante et al., 2012; Philipp and Hoelzle, 2012; Walker et al., 2009). These composts may contain some advantageous residual components, such as stabilizing colloidal factors of biogas digestate but they have not been tested for their effect on allochthonous microorganisms.

The group of microorganisms that are able to degrade alkanes is extremely diverse. Bacterial species belonging to various divisions and fungal species belonging to various taxa can assimilate alkanes as sole carbon source (Das and Chandran, 2010). The quantitative relation of microbial population is markedly influenced by temperature among the physical factors (Farrell and Rose, 1967). The viability of steady-state cells decreases at higher temperature. The integrity of cell membrane can be protected by some inorganic materials with large surfaces, porous and chemically indifferent structures, the application of burnt silica rocks. Recently, perlite became particularly well-known in the field of maintenance of bacterial cells (Daza et al, 2000). Perlite may also be suitable for the extension of the viability of fungal cells (Homolka et al., 2007, Homolka and Lisá, 2008).

The objective of this study was to determine the effect of the compost processed from biogas digestate sourced from the mixture of mycelium residue of oyster mushroom production and swine slurry on the survival of alkane degrading microorganisms belonging to different groups. The survival of microbes was followed not only by direct testing of their activity but also by re-culturing their living cells. The cell quantity of alkane degrading microorganism was compared at room temperature and at a lower, storing temperature in the presence or absence of perlite. 


\section{Materials and methods}

\section{Compost and microorganisms}

The compost medium used in this study was processed in an aerated static pile composting system from the mixture of biogas digestate $(60 \% \mathrm{dw})$, vinasse $(20 \% \mathrm{dw})$, wheat straw $(15 \% \mathrm{dw})$, poultry manure $(4 \% \mathrm{dw})$ and microbial inoculants $(1 \% \mathrm{dw}), 6$ months before the beginning of the experiments. Physical and chemical parameters of the applied biogas digestate compost were the following: electric conductivity, $5.62 \mu \mathrm{S}$ $\mathrm{cm}^{-1} ; \mathrm{pH}, 7.2$; total organic matter, $59.66 \%$; total nitrogen, $1.6 \%$; and carbon:nitrogen ratio 16:1. The biogas digestate compost used in the experiments was previously sterilized by chloroform fumigation.

Four Gram-negative (Brevundimonas vesicularis SM-0625, Chryseobacterium hungaricum CHB-20p, Pseudomonas putida NCP-3, P. putida NC-1494), seven Grampositive bacterial strains (Rhodococcus aetherivorans AK-44, $R$. globerulus AK-36, $R$. gordoniae AK-38, $R$. pyridinivorans AK-37, $R$. pyridinivorans CHB-15p, $R$. rhodochrous AK-40, R. erythropolis AK-35) and five fungal strains (Cladosporium cladosporoides CP3, Paecilomyces variotii $\mathrm{Bd} 41$, Rhodotorula minuta CP2, Talaromyces wortmannii KO24, Yarrowia lipolytica Bd22) were used as test microbes. They originated from different hydrocarbon polluted soils in Hungary.

\section{Microcosm-1 for the examination of survival kinetics}

Aliquots of $500 \mathrm{~g}$ of the incubation mixtures were placed in glass jars with a bottom area of $176 \mathrm{~cm}^{2}$ and volume of $3500 \mathrm{~cm}^{3}$. The incubation mixtures consisted of chloroform-fumigated biogas digestate compost and the cell mass of different alkanedegrading microbes with population densities of $10^{9} \mathrm{CFU} \mathrm{\textrm {g } ^ { - 1 }}$ for Gram-negative bacterial strains and $10^{8} \mathrm{CFU} \mathrm{g}{ }^{-1}$ for Rhodococcus and fungal strains, respectively. The Microcosm- 1 systems were incubated for 256 days at $4{ }^{\circ} \mathrm{C}$ and $26{ }^{\circ} \mathrm{C}$ with permanent provision of sufficient air supply and moisture content (55\%). In parallel experiments, microcosms with the same media containing burnt perlite of $5 \%$ dw were also investigated.

\section{Reisolation of alkane-degrading bacteria and fungi from the prepared compost samples}

The survival of the investigated hydrocarbon-degrading microorganisms in the compost samples was monitored with reisolation of their cells in order to determine the decimal reduction time (D-value), the interval of time during which $90 \%$ of the microorganisms are inactivated at a defined temperature. The populations of Gram-negative and Grampositive bacteria were checked 7 times in the 256 day long incubation period (at days 2 , $4,8,16,32,64$ and 128). In order to recover the actual CFU of the different alkanedegrading bacteria or fungi, three different microbiological nutrient media were used. Gram-negative bacteria were cultured on King's B agar (King et al., 1954), whilst Rhodococcus strains (Gram-positive, acid-fast bacteria with highly specific colony morphology) on CAZ-NB agar (von Graevenitz and Pünter-Streit, 1995). The number of fungal elements in the incubation mixtures was followed with the use of neomycin containing potato-dextrose agar (Merck). 


\section{Measurement of alkane degradation by microorganisms}

The alkane-degrading activity of the tested microorganisms was examined by the OxiTop ${ }^{\circledR}$ Control (WTW) manometric system (Microcosm-2). Measurements were carried out in closed vessels at $26{ }^{\circ} \mathrm{C}$ for 96 hours. Each microcosm contained $20 \mathrm{~g}$ experimental mixture, $1 \%(\mathrm{w}: \mathrm{w})$ diesel oil and the tested microorganism in quantities of $10^{6} \mathrm{CFU} \mathrm{g}^{-1}$ in the case of Gram-negative bacteria, and $10^{7} \mathrm{CFU} \mathrm{g}^{-1}$ for rhodococci and fungi. Simultaneously, microcosms supplemented with 5\% (w:w) burnt perlite were also examined. The carbon dioxide production during the degradation of diesel oil compounds was constantly measured. Incubation mixtures without microorganism were applied as controls. To measure the diesel oil originated carbon dioxide, the control carbon dioxide values were subtracted.

\section{Statistical Analyses}

All of the experiments were carried out in triplicates. Data were presented as mean values and standard deviations. Differences between the treatments were determined by one-way analysis of variance. The D-values for the determination of survival of different alkane-degrading microorganisms at $26{ }^{\circ} \mathrm{C}$ were determined from the negative reciprocal of the slopes of the regression lines, using the linear portions of the survivor curves (CFU g ${ }^{-1}$ versus time of incubation).

\section{Results and discussions}

\section{In vitro survival kinetics of alkane-degrading bacteria in biogas digestate compost}

The effect of the chemical factors involved in the compost medium were adequately

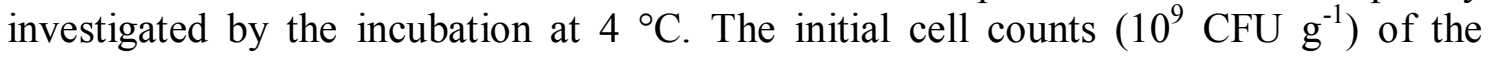
applied Gram-negative alkane-degrading bacterial strains (Brevundimonas vesicularis SM-0625, Chryseobacterium hungaricum CHB-20p, Pseudomonas putida NCP-3) gradually decreased to the value $10^{8} \mathrm{CFU} \mathrm{g}^{-1}$ during the incubation period of 128 days in the examination system Microcosm-1. Following the process of culturing with enumeration, the quantity of the cells decreased by $8-28 \%$ until day 2 and $32-49 \%$ until day 4 (Fig. 1a).

The examined Chryseobacterium hungaricum strain (CHB-20p) proved to be the most tolerant towards the physical and chemical factors reducing the quantity of cells. It was present in the compost in the amount of $9.3 \times 10^{8}, 6.2 \times 10^{8}$ and $5.1 \times 10^{8} \mathrm{CFU} \mathrm{g}^{-1}$ on day 2, 8 and 32, respectively. The survivability of Brevundimonas vesicularis SM0625 was lower than that of Chryseobacterium hungaricum CHB-20p during the examination; the amount of its reculturable cells was $9.2 \times 10^{8}, 6.8 \times 10^{8}$ but $1.7 \times 10^{8}$ $\mathrm{CFU} \mathrm{g}^{-1}$ on day 2, 4 and 64, respectively. Pseudomonas putida NCP-3 survived the least between the three examined alkane-degrading Gram-negative bacterial strains. Its cells remained reculturable in the rate of $20.7 \%$ and $12.6 \%$ on day 32 and 64 , respectively.

The survival of the three examined alkane-degrading Gram-negative bacterial strains showed similar kinetics, the quantity of their cells decreased continuously in the compost mixture. Nevertheless, approximately $10 \%\left(10^{8} \mathrm{CFU} \mathrm{g}^{-1}\right)$ of the initial cells were reculturable until the end of the experiment.

In contrast, the survival of cells of the tested alkane-degrading Gram-negative bacteria belonging to the division Gammaproteobacteria is very limited since these bacteria do not form endospores or any other durable cells. However, their metabolism 
including their respiration level is relatively high. They can minimize the harmful effects of contaminants by their motility and extremely broad spectrum of catabolic enzymes that make a remarkably fast adaptation possible. These bacteria are not responsible for composting and they usually do not live in compost. Their long-lasting survival can be explained by their resistance to the antimicrobial substances of compost or by the presence of metabolizable residues of the compost mixture.
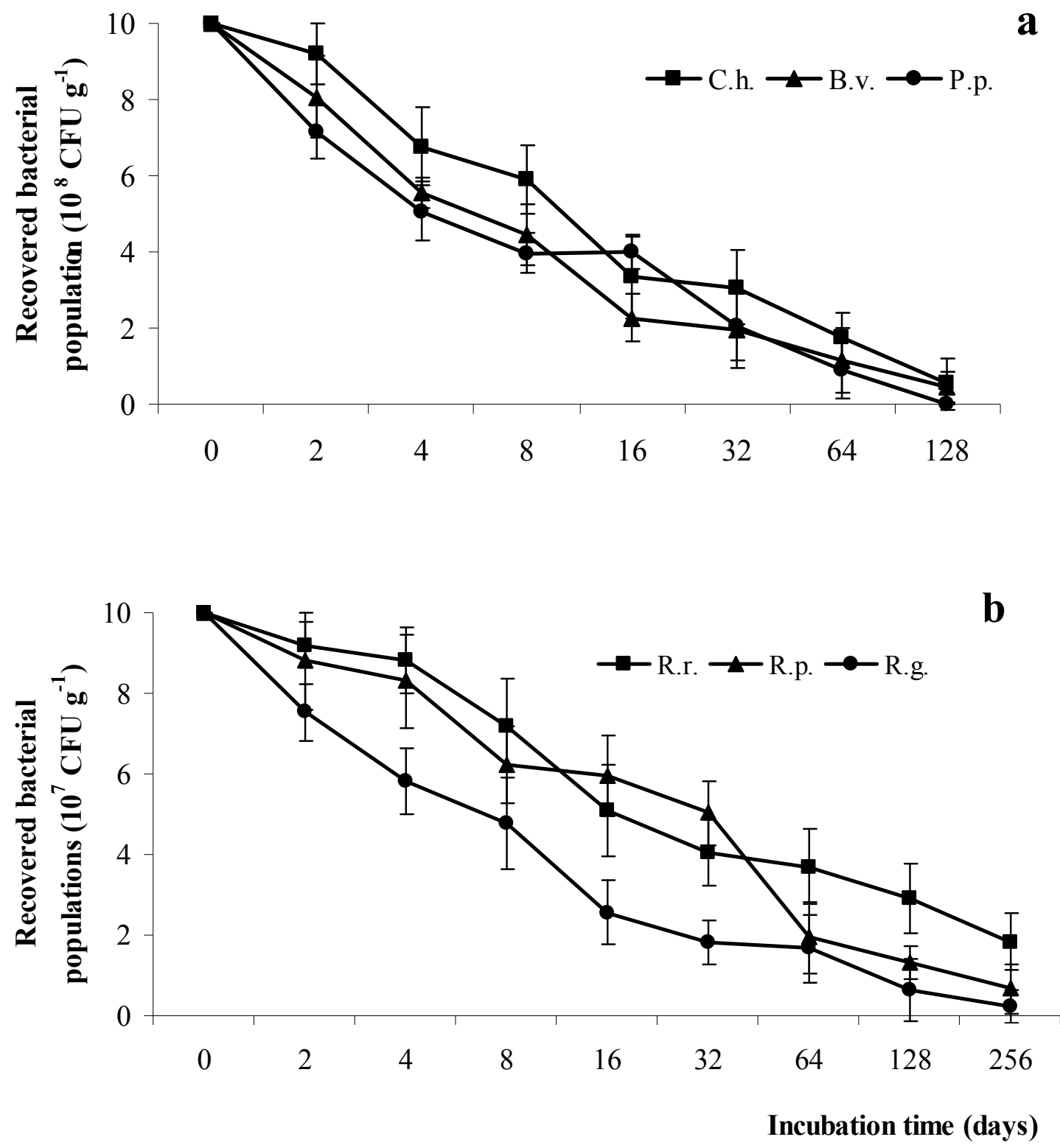

Figure 1. In vitro survival of alkane-degrading Gram-negative (a) and Gram-positive bacteria (b) in biogas digestate compost at $4{ }^{\circ} \mathrm{C}$.

(B.v.: Brevundimonas vesicularis SM-0625, C.h.: Chryseobacterium hungaricum CHB-20p, P.p.: Pseudomonas putida NCP-3, R.p.: R. pyridinivorans AK-37, R.g.: R. gordoniae AK-38, R.r.: R. rhodochrous AK-40) 
Colloidal compatibility of glycocalyx covering the Gram-negative bacterial cells with biogas digestate residues can also be a factor in their survival. The fundamental biological reason of the very similar survival kinetics of the examined bacterial strains in the biogas digestate compost can be explained by their close taxonomic relations to each other and by their similar phenotypic features, especially regarding their cell structure.

The initial cell count $\left(10^{8} \mathrm{CFU} \mathrm{g}{ }^{-1}\right)$ of all the three alkane-degrading Rhodococcus strains, representing Gram-positive prokaryotes in the experiment (Microcosm-1) decreased moderately to the level of $10^{7} \mathrm{CFU} \mathrm{g}^{-1}$ during the 256 day long incubation period at $4{ }^{\circ} \mathrm{C}$. Nevertheless, the survival kinetics of the Rhodococcus strains slightly differed from each other (Fig. 1b).

The first type of the survival kinetics of the Rhodococcus strains were represented by $R$. rhodochrous AK-40 and $R$. pyridinivorans CHB-15p: 83-88\% of their cells could be recultured on day 4 . The cell count of the $R$. rhodochrous AK-40 decreased by half during the first 16 days but it was still $1.8 \times 10^{7} \mathrm{CFU} \mathrm{g}{ }^{-1}$ after the 256 day long incubation period. The survival kinetics of $R$. pyridinivorans CHB-15p slightly differed from the previously mentioned AK-40 strain since its cell density halved after day 32 but $0.7 \times 10^{7}$ living cell was found on day 256. The survival kinetics of $R$. gordoniae AK-38 represents the second type. The cells of the strain AK-38 are apparently less viable in the compost: its survival kinetics show a fast decline until day 4 , and only the half and the quarter of the amount of the cells could be recultured on day 8 and day 16 , respectively. Later on, the fast decline slowed down and the level of $10^{7} \mathrm{CFU} \mathrm{g}{ }^{-1}$ was still present on day 256.

The longer survival of rhodococci can be connected with the bigger size of their cells and genomes, the thicker cell wall consisting of more layers and their wide range catabolic activity. In general, more than $20 \%$ of the cells of the Rhodococcus strains were present at a viable state in the incubation mixture on day 64 . Therefore, we suggest that they contribute to thehydrocarbon degrading activity.

\section{Reduction of the viability of different alkane-degrading bacteria and fungi}

In vitro survival of the different alkane-degrading bacteria and fungi during the longterm incubation in microcosms (Microcosm-1) was characterized by the decimal reduction time ( $\mathrm{D}$-value) in chloroform-fumigated biogas digestate compost (Table 1).

The reduction rate of the cell counts of 4 alkane-degrading strains of Gram-negative bacteria was examined in the pure compost media stored at $4{ }^{\circ} \mathrm{C}$. The Chryseobacterium hungaricum CHB-20p strain proved to be the most tolerant (with a D-value of 128.1 days) while Pseudomonas putida NC-1494 strain (D-value: 49.7 days) was the least tolerant among the examined strains. The effect of incubation temperature on the survival kinetics of all Gram-negative bacteria was significant. At $26^{\circ} \mathrm{C}$, the D-values of the examined strains ranged from 3.1 to 5.5 with an average of 3.9 days. The Dvalues for all tested Gram-negative bacteria indicated that their survival in biogas digestate compost were moderate to weak.

Based on their D-values, the tested Gram-positive strains, namely the examined species of genus Rhodococcus were the most tolerant microorganisms among the alkane-degrading ones of our collection. The majority of them could tolerate the pure compost up to the survival ratio of $10 \%$ for approximately 100-250 days (with an average of 174.6) at $4{ }^{\circ} \mathrm{C}$. The strain $R$. erythropolis AK-35 was the least tolerant (Dvalue: 105.1 days) while the strain $R$. pyridinivorans AK-37 was the most tolerant (D-

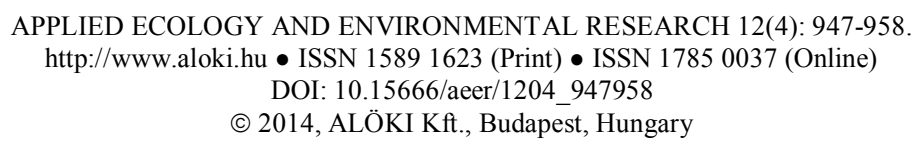


value: 248.6 days) organism in the examined group. An extraordinary D-value ( $>256$ days) was shown by the strain $R$. rhodochrous AK-40 due to its unusual survival kinetics. The effect of incubation temperature on the survival of all examined Rhodococcus strains was also significant. At $26{ }^{\circ} \mathrm{C}$, D-values for rhodococci ranged from 6.3 to 12.8 days with an average of 9.7.

The D-values for the 5 alkane-degrading fungal strains ranged from 64.9 to 151.7 days with an average of 109.3 at $4{ }^{\circ} \mathrm{C}$. They were found to be more tolerant to the ambient compost than the strains of the examined Gram-negative species but less tolerant than the Rhodococcus strains. The effect of incubation temperature was the least pronounced on the survival of the tested fungal strains. D-values determined on the basis of their colony-forming units ranged from 24.4 days (Rhodotorula minuta $\mathrm{CP} 2$ ) to 40.3 days (Talaromyces wortmannii $\mathrm{KO} 24$ ) at $26{ }^{\circ} \mathrm{C}$.

Table 1. Decimal reduction time (D-value) for different alkane-degrading bacteria and fungi within a long-term incubation in mixtures with biogas digestate compost

\begin{tabular}{l|c|c|c|c}
\hline \multirow{2}{*}{ Strains } & \multicolumn{4}{|c}{ D-value (days) } \\
\cline { 2 - 5 } & \multicolumn{2}{|c}{ Pure compost } & \multicolumn{2}{c}{ Compost-perlite mixture } \\
\cline { 2 - 5 } & $\mathbf{4}^{\circ} \mathbf{C}$ & $\mathbf{2 6}^{\circ} \mathbf{C}$ & $\mathbf{4}^{\circ} \mathbf{C}$ & $\mathbf{2 6}{ }^{\circ} \mathbf{C}$ \\
\hline Gram-negative bacteria & & & & \\
Brevundimonas vesicularis SM-0625 & 110.6 & 3.5 & 93.8 & 33.5 \\
Chryseobacterium hungaricum CHB-20p & 128.1 & 5.5 & 124.6 & 48.0 \\
Pseudomonas putida NCP-3 & 96.3 & 3.1 & 68.9 & 21.5 \\
P. putida NC-1494 & 49.7 & 3.6 & 57.5 & 23.9 \\
Gram-positive bacteria & & & & \\
Rhodococcus aetherivorans AK-44 & 176.9 & 6.3 & 258.0 & 187.4 \\
R. globerulus AK-36 & 124.6 & 12.4 & 147.9 & 121.6 \\
R. gordoniae AK-38 & 146.8 & 7.5 & 203.5 & 189.5 \\
R. pyridinivorans AK-37 & 248.6 & 9.2 & $>256$ & $>256$ \\
R. pyridinivorans CHB-15p & 164.5 & 8.4 & 197.5 & 175.0 \\
R. rhodochrous AK-40 & $>256$ & 11.3 & $>256$ & $>256$ \\
R. erythropolis AK-35 & 105.1 & 12.8 & 137.3 & 126.7 \\
Fungi & & & & \\
Cladosporium cladosporoides CP3 & 64.9 & 27.9 & 94.7 & 33.1 \\
Paecilomyces variotii Bd41 & 96.5 & 32.7 & 208.5 & 182.7 \\
Rhodotorula minuta CP2 & 83.8 & 24.4 & 199.2 & 50.6 \\
Talaromyces wortmannii KO24 & 149.4 & 40.3 & 196.8 & 49.0 \\
Yarrowia lipolytica Bd22 & 151.7 & 38.4 & 182.3 & 68.9 \\
\hline
\end{tabular}

During composting, the easily biodegradable materials are converted to more stable organic materials,e.g. humic and fulvic acids. These acids are not only slowly metabolizable compounds but they also have some antimicrobial effect. The tolerance of the effect of humic materials was a major factor in the selection of our alkanedegrading test microorganisms. Based on the results, the chosen strains were able to survive easier for a shorter or a longer period of time in compost. We also suppose that some special colloid compounds in the biogas digestate compost increased the survival rate of the tested microorganisms.

The Gram-negative bacteria with smaller cells and thinner cell wall were more sensitive to different abiotic effects and their survival was shorter than that of the rhodococci with larger cell size, more extended genome and multilayered cell wall. The 
survival of the fungi can be explained by their big cells, thick cell wall and their the eukaryote cell structure.

The survival of the alkane-degrading bacteria in the biogas digestate compost containing burnt perlite was generally longer than in the pure compost. The survival kinetics of the tested Gram-negative strains in the perlite-containing compost at $4{ }^{\circ} \mathrm{C}$ slightly differed from that in the pure compost at the same temperature. In the perlitecontaining compost media, D-values for the tested Gram-negative bacteria varied between 57.5 (Pseudomonas putida NC-1494) and 124.6 (Chryseobacterium hungaricum CHB-20p) days with an average of 86.2 days. While the effect of perlite was not significant at $4{ }^{\circ} \mathrm{C}$, the perlite contentmarkedly increased the D-values of Gramnegative bacteria at $26^{\circ} \mathrm{C}$. They ranged between 21.5 and 48.0 days with an average of 31.7 days.

The presence of perlite in compost medium caused a moderately increased survival of the tested Rhodococcus strains at $4{ }^{\circ} \mathrm{C}$. For 5 isolates, the D-values ranged between 137.3 and 240.0, and in the case of 2 strains the determined value exceeded the experimental period of 256 days. The most outstanding effect of the perlite content was found in the case of the survival of rhodococci at $26^{\circ} \mathrm{C}$. D-values for 5 of them varied between 121.6 and 232.0 with an average of 168.9 and the cell count of the further 2 Rhodococcus strains ( $R$. pyridinivorans $\mathrm{AK}-37$ and $R$. rhodochrous $\mathrm{AK}-40$ ) did not decrease to $10 \%$ in the perlite-containing compost during the 256-day long incubation.

In the case of fungal strains, a significant elongation of the survival could be observed in the compost containing perlite at $4{ }^{\circ} \mathrm{C}$. The D-values of fungal survival increased with the average of $60 \%$ in the presence of perlite in the compost medium. The effect of perlite in the medium was remarkable at $26{ }^{\circ} \mathrm{C}$, too. Colony forming units of 4 fungal strains increased in a similar rate in spite of the fact that they are not strongly related taxonomically. The blastoconidia of Cladosporium cladosporoides $\mathrm{CP} 3$, the phialoconidia of Talaromyces wortmannii KO24 and the budding cells of Rhodotorula minuta $\mathrm{CP} 2$ and Yarrowia lipolytica $\mathrm{Bd} 22$ showed an average $65 \%$ longer survival in the presence of perlite than in the pure compost at $26^{\circ} \mathrm{C}$. The survival of the phialoconidia of Paecilomyces variotii $\mathrm{Bd} 41$ in the perlite-containing compost was also improved by perlite in the compost compared to pure compost at the same temperature.

The increase of the survival of different alkane-degrading microbe strains in biogas digestate compost containing burnt perlite at proportion of $5 \%$ can be considered as a complex phenomenon. As for the effect on the survival of Gram-negative bacterial strains, burnt perlite can provide a chemically inert large surface for the immobilisation of biologically intact cells. Besides, especially for rhodococci and fungi, perlite stabilizes the optimal humidity and aeration of compost medium.

\section{Carbon dioxide production of the prepared hydrocarbon-containing mixtures}

During the degradation of components of the diesel oil added to the biogas digestate compost, carbon-dioxide produced by the alkane-degrading microorganisms was constantly measured in microcosm experiments (Microcosm-2). Results are summarized in Table 2. In the examined aerobic microcosms, high level respiration (9.2-14.6 $\mu \mathrm{g}$ $\mathrm{CO}_{2} \mathrm{~g}^{-1} \mathrm{~h}^{-1}$ ) was found in the case of Gram-negative bacterial strains with the initial cell count of $10^{7} \mathrm{CFU} \mathrm{g}{ }^{-1}$. The highest carbon dioxide production was showed by the strain Pseudomonas putida NCP-3 while the carbon dioxide production of Chryseobacterium hungaricum CHB-20p was considerable, too. The respiration level of Rhodococcus strains introduced into the system at the amount of $10^{6} \mathrm{CFU} \mathrm{g}^{-1}$ was also relatively high 
(5.8-9.6 $\left.\mu \mathrm{g} \mathrm{CO}_{2} \mathrm{~g}^{-1} \mathrm{~h}^{-1}\right)$. The highest carbon dioxide production of rhodococci was found for the strain $R$. pyridinivorans AK-37. The respiration level of hydrocarbon degrading fungal strains in the presence of diesel oil was also remarkable. The carbon dioxide production $\left(9.1 \mu \mathrm{g} \mathrm{CO}_{2} \mathrm{~g}^{-1} \mathrm{~h}^{-1}\right)$ of the well known hydrocarbon degrader Yarrowia lipolytica $\mathrm{Bd} 22$ is followed by that of the strain Rhodotorula minuta CP2 (6.0 $\left.\mu \mathrm{g} \mathrm{CO} \mathrm{g}^{-1} \mathrm{~h}^{-1}\right)$. It can be concluded that the different hydrocarbon degrading strains not only can survive as viable cells in the biogas digestate compost but they can also degrade the alkanes of diesel oil added to the incubation mixture.

Table 2. Carbon dioxide production of alkane-degrading microbial strains in compost or compost-perlite composition with the addition of diesel oil

\begin{tabular}{|c|c|c|}
\hline \multirow{2}{*}{ Strains } & \multicolumn{2}{|c|}{$\begin{array}{c}\text { Carbon-dioxide production }\left(\mu \mathrm{g} \mathrm{CO}_{2} \mathrm{~g}^{-1} \mathrm{~h}^{-1}\right) \\
\text { by alkane degradation } \\
\end{array}$} \\
\hline & Compost & $\begin{array}{l}\text { Compost-perlite } \\
\text { mixture }\end{array}$ \\
\hline \multicolumn{3}{|l|}{ Gram-negative bacteria } \\
\hline Brevundimonas vesicularis SM-0625 & $9.2 \pm 0.9$ & $10.7 \pm 0.9$ \\
\hline Chryseobacterium hungaricum CHB-20p & $11.9 \pm 1.1$ & $9.2 \pm 0.8$ \\
\hline Pseudomonas putida NCP-3 & $14.6 \pm 1.2$ & $14.9 \pm 1.0$ \\
\hline P. putida $\mathrm{NC}-1494$ & $10.3 \pm 0.9$ & $12.3 \pm 1.1$ \\
\hline \multicolumn{3}{|l|}{ Gram-positive bacteria } \\
\hline Rhodococcus aetherivorans AK-44 & $7.5 \pm 0.4$ & $7.1 \pm 0.5$ \\
\hline R. globerulus AK-36 & $8.4 \pm 0.6$ & $8.2 \pm 0.5$ \\
\hline R. gordoniae AK-38 & $6.7 \pm 0.4$ & $10.5 \pm 0.7$ \\
\hline R. pyridinivorans $\mathrm{AK}-37$ & $9.6 \pm 0.7$ & $14.8 \pm 0.9$ \\
\hline R. pyridinivorans $\mathrm{CHB}-15 \mathrm{p}$ & $7.4 \pm 0.5$ & $13.6 \pm 0.9$ \\
\hline R. rhodochrous AK-40 & $5.8 \pm 0.3$ & $12.4 \pm 0.7$ \\
\hline R. erythropolis AK-35 & $6.2 \pm 0.4$ & $11.7 \pm 0.7$ \\
\hline \multicolumn{3}{|l|}{ Fungi } \\
\hline Cladosporium cladosporoides CP3 & $4.4 \pm 0.8$ & $7.9 \pm 1.4$ \\
\hline Paecilomyces variotii $\mathrm{Bd} 41$ & $5.1 \pm 0.4$ & $8.0 \pm 0.5$ \\
\hline Rhodotorula minuta $\mathrm{CP} 2$ & $6.0 \pm 0.8$ & $7.9 \pm 0.9$ \\
\hline Talaromyces wortmannii $\mathrm{KO} 24$ & $4.8 \pm 1.1$ & $5.2 \pm 0.8$ \\
\hline Yarrowia lipolytica $\mathrm{Bd} 22$ & $9.1 \pm 1.4$ & $9.3 \pm 0.9$ \\
\hline
\end{tabular}

All representatives of the three examined taxonomic groups of the alkane-degrading microbial strains produced carbon dioxide during the degradation of diesel oil added to the compost mixture even in the presence of 5\% perlite. The respiration of the applied Gram-negative bacterial strains incubated in the compost-perlite mixture did not significantly differ from that incubated in pure compost. However, the majority of the applied Rhodococcus strains produced significantly more carbon dioxide in the perlitecontaining incubation medium. Similarly to rhodococci, the majority of the applied fungi showed an increased activity due to the effect of perlite in the compost mixture.

The presence of perlite in the incubation mixture increased the respiration activity of the applied Rhodococcus strains outstandingly. It was moderately increased for applied fungal strains while no effect was found concerning that of the Gram-negative strains. Several physical and chemical factors can be considered as the natural background of the effect of perlite application. One of the most important factors may be the water activity stabilizing effect of perlite being advantageous for actinobacteria and fungi. 


\section{Adaptability of the applied bacteria to hydrocarbons}

During the 96-hour long incubation period of previously fumigated and diesel oil containing experimental mixtures inoculated with alkane-degrading bacteria, carbon dioxide evolved in two different phases (Microcosm-2). At 12-24 hours of the incubation, the average rate of carbon dioxide production of the cells of the 3 alkanedegrading Gram-negative bacterial strains (Brevundimonas vesicularis SM-0625, Cryseobacterium hungaricum CHB-20p, Pseudomonas putida NCP-3) was 8.2, 10.4 and $11.7 \mathrm{CO}_{2} \mathrm{~g}^{-1} \mathrm{~h}^{-1}$, respectively. At 84-96 hours the values of $10.1,12.8$ and $15.5 \mu \mathrm{g}$ $\mathrm{CO}_{2} \mathrm{~g}^{-1} \mathrm{~h}^{-1}$ were measured as maximal respiration intensity of these strains. The average carbon dioxide production of the tested 3 Rhodococcus strains ( $R$. pyridinivorans AK$37, R$. gordoniae AK-38, $R$. rhodochrous AK-40) was only $1.4,1.2$ and $1.8 \mathrm{CO}_{2} \mathrm{~g}^{-1} \mathrm{~h}^{-1}$ at 12-24 hours. In contrast, at 84-96 hours, the determined values were 10.4, 7.6 and 6.7 $\mathrm{CO}_{2} \mathrm{~g}^{-1} \mathrm{~h}^{-1}$, respectively (Fig. 2).

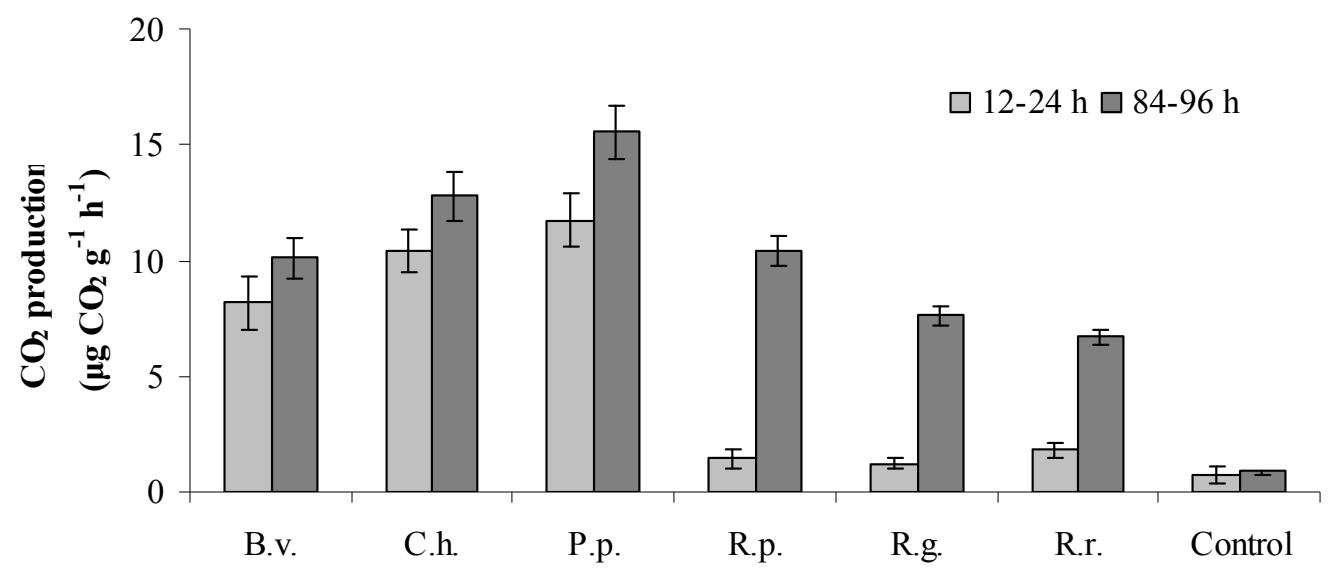

Figure 2. Carbon-dioxide production of the experimental mixtures prepared with different alkane-degrading bacteria at 12-24 and 72-96 hours of incubation.

(B.v.: Brevundimonas vesicularis SM-0625, C.h.: Chryseobacterium hungaricum CHB-20p,

P.p.: Pseudomonas putida NCP-3, R.p.: R. pyridinivorans AK-37, R.g.: R. gordoniae AK-38, R.r.: R. rhodochrous $A K-40$, Control: non inoculated experimental mixtures)

In the first phase, the respiration intensity of the Gram-negative strains reached quickly $75.5-81.5 \%$ of their maximum while Rhodococcus strains were able to reach only $13.7-27.4 \%$ of their maximum value at the same time. The difference in the carbon dioxide production between the examined two groups of bacteria suggests that they differ markedly in the adaptability to the presence of hydrocarbons.

\section{Conclusions}

Based on our results, the cell quantity of the tested 3 alkane-degrading Gramnegative bacterial strains gradually decreased from the initial $10^{9} \mathrm{CFU} \mathrm{g}^{-1}$ to a minimum value in the compost during the 128 -day long incubation at $4^{\circ} \mathrm{C}$. Furthermore, $10 \%$ of the cells survived for approximately 50-90 days (D value). The survival kinetics of the population of the 3 alkane-degrading Rhodococcus strains was longer; it took 100-200 days to decrease to $10 \%$ of the initial cell quantity $\left(10^{8} \mathrm{CFU} \mathrm{\textrm {g } ^ { - 1 }}\right)$ at $4{ }^{\circ} \mathrm{C}$. Moreover,

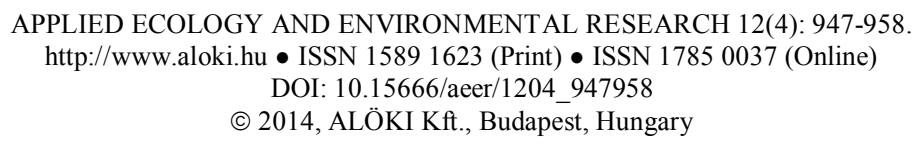


nearly $20 \%$ of the cells of the strain $R$. rhodochrous AK-40 were present in the compost even at the end of the 256 days long incubation period. Interestingly, $R$. gordoniae of rhodococci represented a different type of survival kinetics: it rapidly decreased its number in the first week. Furthermore, ten percent of the initial cell quantity $\left(10^{8} \mathrm{CFU}\right.$ $\left.\mathrm{g}^{-1}\right)$ of the fungi, representing eukaryote microorganisms with a chitinous cell wall, has survived for 65-105 days.

The results also indicate that the survival of both the bacterial and fungal strains depended considerably on the temperature of the compost. At $26{ }^{\circ} \mathrm{C}$, the survival of Gram-negative bacteria and rhodococci was $94 \%$ lower than at $4{ }^{\circ} \mathrm{C}$ while the survival of fungi was $70 \%$ lower at $4{ }^{\circ} \mathrm{C}$ than at $26{ }^{\circ} \mathrm{C}$. Burnt perlite added to the system in the volume of $5 \%$ to stabilize the porosity and the water activity of the compost increased the survival of bacteria by $31 \%$ and that of fungi by $61 \%$ in average.

Based on the carbon dioxide production experiments, we can conclude that the alkane-degrading microbes not only survived in the compost previously fumigated with chloroform but also could utilize the components of the diesel oil added to the system. The Gram-negative bacterial cells of the quantity of $10^{7} \mathrm{CFU} \mathrm{g}{ }^{-1}$ produced 9.2-14.6 $\mu \mathrm{g}$ $\mathrm{h}^{-1}$ carbon dioxide by metabolizing the diesel oil. The rhodococci and the fungal strains, with the cell count of $10^{6} \mathrm{CFU} \mathrm{g}^{-1}$, produced carbon dioxide in less quantity.

While the addition of 5\% perlite to the compost-microorganism-diesel oil incubation mixture did not change significantly the carbon dioxide production of the Gramnegative strains, rhodococci and fungal strains markedly increased their activity.

The adaptability of Gram-negative bacteria and rhodococci to hydrocarbons was found to be markedly different. In the phase of 12-24 hours of the incubation, the quantity of the carbon dioxide produced by Gram-negative bacteria in the course of the metabolism of diesel oil has already reached $75.5-81.5 \%$ of the experienced maximum of the 84-96 hours experiment, while during the same period, Rhodococcus strains reached only $13.7-27.4 \%$ of their maximum values.

In summary, we suggest further investigations of the survival kinetics of each microorganism strain in the adequate media, both for experimental and technological applications.

Acknowledgements. This work was supported by grants NKFP_07-A4(2007)(OM-00120/2007) BIOKOMP4 and Research Centre of Excellence 17586-4/2013/TUDPOL. We are grateful for the excellent technical assistance of Brigitta Edőcs.

\section{REFERENCES}

[1] Bustamante, M.A., Alburquerque, J.A., Restrepo, A.P., de la Fuente, C., Paredes, C., Moral, R., Bernal, M.P. (2012): Co-composting of the solid fraction of anaerobic digestates, to obtain added-value materials for use in agriculture. - Biomass and bioenergy 43: 26-35.

[2] Das, N., Chandran P. (2010): Microbial degradation of petroleum hydrocarbon contaminants: an overview. - Biotechnology Research International, Article ID 941810, p. 13.

[3] Daza, A., Santamara, C., Rodrguez-Navarro D.N., Camacho M., Orive R., Temprano F. (2000): Perlite as a carrier for bacterial inoculants. - Soil Biology and Biochemistry 32: $567-572$. 
[4] de Bertoldi, M., Vallini, G., Pera, A., (1983): The biology of composting: A review. Waste Management and Research 1: 157-176

[5] Elfering, S.J.W.H., van Lis, R., Heilig, H.G.H.J., Akkermans, A.D.L., Stams, A.J.M. (1998): Detection and quantification of microorganisms in anaerobic bioreactors. Biodegradation 9: 169-177.

[6] Farrell, J., Rose, A. (1967): Temperature effects on microorganisms. - Annual Review of Microbiology 21: 101-120.

[7] Haug, R. T. (1993): The practical handbook of compost engineering. Lewis Publishers, CRC Press LLC, Boca Raton, FL, pp. 717.

[8] Homolka, L., Lisá, L. (2008): Long-term Maintenance of Fungal Cultures on Perlite in Cryovials - an Alternative for Agar Slants. - Folia Microbiologica 53: 534-536.

[9] Homolka, L., Lisá, L., Kubátová, A., Váňová, M., Janderová, B., Nerud, F. (2007): Cryopreservation of filamentous micromycetes and yeasts using perlite. - Folia Microbiologica 52: 153-157.

[10] Insam, H., de Bertoldi, M. (2007): Microbiology of the composting process. - In: Diaz, L.F., de Bertoldi, M., Bidlingmaier, W., Stentiford, E. (Eds): Compost science and technology. Waste Management Series 8, Elsevier 25-48.

[11] King, E.O., Ward, M.K., Raney, D.E. (1954): Two simple media for the demonstration of pyocyanin and fluorescin. - Journal of Laboratory and Clinical Medicine 44: 301-307.

[12] Maurer, C., Mueller, J. (2012): Ammonia (NH3) emissions during drying of untreated and dewatered biogas digestate in a hybrid waste-heat/solar dryer. - Engineering in Life Sciences 12: 321-326

[13] Philipp, W., Hoelzle, L.E. (2012): Germs in digestates from biogas plants? Gefahrstoffe- Reinhaltung der Luft 72: 216-220.

[14] von Graevenitz, A., Pünter-Streit, V. (1995): Development of a new selective plating medium for Rhodococcus equi. - Microbiology and Immunology 39: 283-284.

[15] Walker, L., Charles, W., Cord-Ruwisch, R. (2009): Comparison of static, in-vessel composting of MSW with thermophilic anaerobic digestion and combinations of the two processes. -Bioresource and Technology 100: 3799-3807.

[16] Weiland, P. (2010): Biogas production: current state and perspectives. - Applied Microbiology and Biotechnology 85: 849-860. 